\title{
A USINA HIDRELÉTRICADE YACYRETÁ: INSUSTENTABILIDADE E EXCLUSÃO SOCIAL NO RIO PARANÁ (CORRIENTES, ARGENTINA)
}

\author{
Yacyretá dam: unsustainability and social exclusion \\ in the Paraná River (Corrientes, Argentina)
}

\author{
Víctor Ulloa \\ Departamento de Biologia (DBI) - Programa de Pós-Graduação \\ em Ecologia de Ambientes Aquáticos Continentais (PEA), \\ Universidade Estadual de Maringá \\ Maringá/PR - Brasil \\ ulloacamp@hotmail.com \\ Luzia Marta Bellini \\ Professora colaboradora - Programa de Pós-Graduação \\ em Ecologia de Ambientes Aquáticos Continentais (PEA), \\ Universidade Estadual de Maringá \\ Maringá/PR - Brasil \\ martabellini@uol.com.br
}

Artigo recebido para publicação em 07/09/2009 e aceito para publicação em 02/12/2009

RESUMO: A promoção de megaobras é comumente baseada em idéias de desenvolvimento e de progresso. Contudo, o informe apresentado pela Comissão Mundial de Represas em novembro de 2000, responsabilizou às grandes barragens, os projetos de desenvolvimento regional sustentável por excelência, como geradoras de uma série de danos sociais e ambientais. Destarte, o objetivo do artigo é estudar e analisar as transformações sociais ocorridas nas comunidades de ilhéus e ribeirinhos de Ituzaingó a partir das mudanças na paisagem ecológica decorrentes da construção da Usina Hidrelétrica de Yacyretá (Corrientes, Argentina). Desse modo, analisaram-se as características gerais da barragem e as principais contradições ambientais e sociais percebidas na cidade e na comunidade de pescadores-lavradores. Os resultados mostraram, por um lado, que para os ex-ilhéus e ex-ribeirinhos não há medida de mitigação capaz de compensar a perda do seu anterior modo de vida, por outro, uma clara falta de seriedade nas políticas socioambientais de Yacyretá. E ainda, um escasso ou nulo desenvolvimento de Ituzaingó e região após a construção da barragem.

Palavras-chave: Barragem de Yacyretá. Ituzaingó. Megaobras. Rio Paraná.

ABSTRACT: The promotions of mega-constructions are usually based in ideas of development and progress. However, the report showed by the World Commission on Dams in November of 2000, responsabilized the big reservoirs, main projects on sustainable regional development, as generators of social and environmental damages. Thus, the main objective of the present study was to investigate the social transformations in the communities of the islanders and riparian people from Ituzaingó, from the changes in the ecological landscape since the constructions of the hydroelectric power plants of Yacyretá (Corrientes, Argenti- 
na). Thereby, were analyzed the general characteristics of the dam and the main environmental and social contradictions detected in the city and in the traditional communities of the islanders and riparian people. The results showed, in a way, for the ex-islanders and ex-riparian people any mitigation measure is not able to compensate the loss of his previous way of life; and on the other hand, the lack of serious social and environmental politics of Yacyretá dam, and besides of this, a small or no development of Ituzaingó and region after construction of the dam.

Keywords: Yacyretá Dam. Ituzaingó. Mega-Constructions. Paraná River.

\section{INTRODUÇÃO}

Nas décadas de 1960 e 1970 o debate sobre o desenvolvimento econômico no mundo fundamentava-se na idéia segundo a qual os padrões de consumo das minorias que viviam nos países altamente industrializados eram acessíveis às grandes massas de população em rápida expansão do terceiro mundo. A partir dessa idéia, os economistas, principalmente aqueles pertencentes aos países que lideraram a revolução industrial, conceberam complexos esquemas do processo de acumulação de capital no qual o impulso dinâmico era sempre dado pelo progresso tecnológico. Pouca ou nenhuma atenção foi dada às consequências no plano cultural e ambiental de um sistema cujos objetivos últimos eram satisfazer interesses privados (FURTADO, 1974).

Apesar dos primeiros alertas serem anteriores a 1950, é somente durante as décadas de 1960 e 1970 que a preocupação pelos diversos problemas ambientais começa adquirir relevância com a aparição de vários grupos e organizações não governamentais. Em 1972 publica-se o relatório Limites do crescimento (MEADOWS; MEADOWS; RANDERS; BEHRENS, 1972) do Clube de Roma. Graças a esses estudos foram trazidos ao primeiro plano problemas cruciais que os economistas sempre deixaram na sombra. Ainda em 1972 começa a preocupação do sistema político (governos e partidos) em torno da problemática ambiental, fato marcado pela realização da primeira Conferência da Organização das Nações Unidas sobre o Meio Ambiente e o Homem em Estocolmo, Suécia.

À publicação de Limites do crescimento do
Clube de Roma e da Conferência de Estocolmo seguiram-se novos relatórios, eventos e fatos políticoinstitucionais marcados pelo crescente interesse pela problemática ambiental. Nesse sentido, a Conferência da ONU sobre Meio Ambiente e Desenvolvimento (CNUMAD) de 1992 no Rio de Janeiro (Conferência da Terra) foi particularmente importante ao reunir um vasto número de chefes de estados com a finalidade de elaborar estratégias e medidas para deter e reverter à degradação ambiental, bem como para promover 0 desenvolvimento sustentável.

É nesse contexto que, também na década de 1970, surge um novo conceito que rapidamente passou a ocupar o centro de todo discurso ecológico oficial: o desenvolvimento sustentável. Com seus primórdios na Declaração de Cocoyok e o Relatório Dag-Hammarskjöld dos anos de 1970, o desenvolvimento sustentável apareceu nos relatórios da União Internacional para a Conservação da Natureza (IUCN) no início dos anos de 1980, sendo popularizado a continuação no chamado Relatório Brundtland de 1987 da Comissão Mundial sobre o Meio Ambiente e o Desenvolvimento (UNCED). Desenvolvimento sustentável é desenvolvimento que satisfaz as necessidades do presente sem comprometer a capacidade das futuras gerações satisfazerem as suas próprias necessidades. $\mathrm{O}$ Relatório Brundtland dessa forma, sublinha a interligação entre economia, tecnologia, sociedade e política ao tempo de chamar a atenção para uma nova postura ética, caracterizada pela responsabilidade tanto entre as gerações quanto entre os membros contemporâneos da sociedade atual. 


\subsection{As barragens como projetos de desenvolvimen- to regional sustentáveis}

Em outro âmbito, para Boneti (2003), o princípio segundo o qual a modernização dos fatores de produção (novas técnicas, ferramentas, energia, insumos, etc.) se constitui no caminho que conduz a sociedade à plenitude do seu bem-estar, encontra-se sustentado na idéia clássica de que a modernidade está intimamente ligada à razão. Entende-se, desse modo, que a modernidade é uma representação racional porque ela é efetivada pela técnica, a qual tem origem em uma ciência de caráter infalível. A idéia da modernização da produção, quando associada à técnica, institui a pressuposição de que a modernidade traz, necessariamente, o bem comum para todos os segmentos sociais. Esse é um pressuposto básico do paradigma dominante do desenvolvimento no qual o Estado brasileiro e demais países da região buscam sua sustentação teórica para fomentar o desenvolvimento social e econômico. Na prática, porém, ainda segundo Boneti (2003), diferentes experiências agrícolas têm mostrado que quando se procede à substituição dos fatores de produção mediante o desenvolvimento tecnológico provoca-se uma mudança estrutural conjunta na base tecnológica de produção, nas suas relações e no meio ambiente. Isto é, quando ocorre uma intervenção do Estado numa realidade social visando a transformação da sua base produtiva constata-se que o processo de transformação do sistema tradicional de produção no sistema moderno não se dá sob efeitos de acomodação ou de absorção, mas, ao contrário, pelo desenvolvimento de um processo de exclusão e de eliminação.

As intervenções dos Estados em determinadas realidades sociais ocorrem atualmente por meio dos chamados projetos de desenvolvimento regional sustentável. Esses projetos costumam promover obras, normalmente megaobras, marcadas por pretensões de validade baseadas em idéias de desenvolvimento sustentável e de progresso social. Nesse sentido, para Ribeiro (1999), os projetos de desenvolvimento regional sustentável, com uma legitimidade baseada em ambíguos discursos tecnicistas e na contemplação de áreas isoladas para sua realização, são os responsáveis por gerar a idéia, segundo a qual, “esse projeto” é a melhor e mais razoável solução para um problema econô- mico ou social de alcance regional ou nacional.

Seja por tomada de decisões precipitadas ou pela ausência de objetivos claros dos projetos, o certo é que a experiência brasileira em matéria de desenvolvimento sustentável é, no mínimo, controvertida. Isto não ocorre somente pelas diversas problemáticas ambientais produzidas, mas especialmente pelas consequências desastrosas causadas aos ocupantes originais das áreas consideradas, sobretudo às populações indígenas.

A barragem de Balbina é, talvez, o caso mais polêmico e controvertido em matéria de desenvolvimento hidrelétrico brasileiro da década de 1970. Balbina foi construída no rio Uatumã, no centro da região Amazônica, para fornecer energia elétrica a Manaus. A usina é um dos projetos conhecidos no Brasil como "obras faraônicas" por exigir o esforço de toda uma sociedade em troca, praticamente, de nada (FEARNSIDE, 1990). A construção de Balbina significou a perda de mais de $4.000 \mathrm{~km}^{2}$ de florestas para produzir apenas 240 MW. Centenas de famílias nãoindígenas e indígenas foram prejudicadas. A população ribeirinha perdeu o peixe, a caça, a água, sendo que somente uma pequena parte deles recebeu efetiva assistência das Centrais Elétricas do Norte do Brasil (ELETRONORTE). Já o episódio indígena, ou o massacre dos Waimiri-Atroari, foi tão grave que o Brasil foi acusado de genocídio no Quarto Tribunal Bertrand Russell, em Rotterdam, Holanda, em novembro de 1980 (FEARNSIDE, 1990).

Na Argentina, por sua vez, a situação não é muito diferente em matéria de desenvolvimento sustentável. Assim, por exemplo, o objetivo para a construção da usina hidrelétrica de Salto Grande na Provincia de Entre Ríos, estampado nos convênios reversais entre a Argentina e a República Oriental do Uruguai, deixou absolutamente claro que o desenvolvimento regional era a premissa básica desse complexo binacional. Porém, depois de mais de vinte anos de conclusão dessa obra, nenhum grande desenvolvimento regional foi observado na área. Para a realização do projeto de Salto Grande não foram considerados os possíveis impactos ambientais e sociais resultantes da construção e operação da barragem. A biodiversidade da biota do rio Uruguai foi atingida de tal maneira que várias espécies de esponjas, moluscos e peixes, no tre- 
cho a montante da barragem, desapareceram (BONETTO; HURTADO, 1999). O impacto sofrido pelos habitantes de Federación, a cidade entrerriana mais afetada pela obra, constituiu-se em um problema sem solução até hoje dado o não cumprimento dos governos provincial e nacional em assegurar os recursos necessários para o deslocamento dos moradores para outro local (CARLOS CECCO, 2002).

Em novembro de 2000, o relatório final (Barragens e desenvolvimento: um novo modelo para tomada de decisões) da Comissão Mundial de Barragens (CMB), responsabilizou às grandes barragens, os projetos de desenvolvimento regional sustentável por excelência, como geradoras de uma infinidade de danos sociais e ambientais, entre outros, o deslocamento de entre 40 a 80 milhões de pessoas em todo o mundo; o comprometimento dos meios de subsistência de milhões de pessoas que viviam rio abaixo e rio acima das represas, em particular daquelas que dependiam das planícies de inundação natural e da pesca; a degradação das bacias rio acima devido à inundação da zona dos reservatórios; os impactos negativos nos meios de subsistência, cultura e espiritualidade de grupos indígenas, tribais e minorias étnicas; a perda de habitat natural e da biodiversidade aquática (COMISSÃO MUNDIAL DE BARRAGENS, 2005).

\subsection{A bacia do Plata e os pescadores-lavradores do rio Paraná}

A bacia do Plata com $3.100 .000 \mathrm{~km}^{2}$ é a segunda bacia da América do Sul em área depois da bacia Amazônica e a quinta no mundo. Apesar de envolver regiões da Bolívia, Paraguai e Uruguai, o Brasil e a Argentina possuem 75,1 \% da área total. A bacia apresenta quatro grandes rios coletores, o Paraná, o Paraguai, o Uruguai e o rio da Plata (CAUBET, 1991). Associadas às bacias hidrográficas de cada um desses rios, a bacia do Plata apresenta diversas áreas úmidas na forma de planícies de inundação. As planícies de inundação, por sua vez, são definidas como macroecossistemas (NEIFF, 1990) de grande complexidade funcional e estrutural (NEIFF, 1990; WARD; STANFORD, 1995), de elevada diversidade de espécies (STANFORD; WARD; LISS; FRISSELL; WILLIAMS; LICHATOWICH; COUTANT, 1996,
WARD; TOCKNER; SCHIEMER, 1999), sendo considerados ecossistemas altamente produtivos (JUNK, 1980; LEWIS; WEIBEZAHN; SAUNDERS III; HAMILTON, 1990).

Dentre os numerosos assentamentos humanos que habitam as ilhas e margens do rio Paraná, é possível distinguir uma série, embora dinâmica, de representações sociais, entre outras, lavradores, pescadores, pescadores-lavradores, oleiros, ceramistas, pecuaristas e até assalariados tentando fugir do aluguel das cidades próximas. Contudo, a representação dos pescadores-lavradores é, talvez, a comunidade mais numerosa e que mais se repete ao longo do rio Paraná. A sobrevivência da maioria desses grupos está baseada em sistemas de produção fundamentados na interação direta com o meio físico. Assim, no caso dos pescadores-lavradores, é pelo trabalho familiar, realizado na lavoura e no rio, que este grupo assegura sua manutenção. Muitas destas comunidades, além da lavoura e da pesca, complementam as suas rendas pelo uso tradicional de outros recursos naturais, como a caça de animais silvestres e a coleta de mel e de plantas medicinais.

No caso específico do rio Paraná, Petrere e Agostinho (1993) distinguem a existência de três tipos de pescarias ainda em exercício no canal principal do rio: artesanal, esportiva e de subsistência. De acordo com essa classificação, os pescadores-lavradores enquadrar-se-iam no terceiro tipo, ou seja, pescadores de subsistência por se apresentarem como "pequeños agricultores y trabajadores a tiempo parcial que cortan la caña durante la recolección ("bóias frias"), residentes en las incontables islas del río, donde cultivan cereales o viven en pequeñas concentraciones en la orilla del río”. [...] La pesca de subsistencia es practicada por casi todos los habitantes de las islas y por una parte considerable de la población que vive en las proximidades del río, hasta el punto de que representa la principal fuente de proteína para estas personas".

\subsection{Ituzaingó, sede argentina da barragem de Yacyretá}

A cidade de Ituzaingó $\left(27^{\circ} 36^{\prime} \mathrm{S}, 56^{\circ} 41^{\prime} \mathrm{W}\right)$, foi fundada em 1864 sobre a margem esquerda do 
Alto rio Paraná, no extremo nordeste da Provincia de Corrientes (FIG. 1). Localiza-se a uma distância aproximada de $230 \mathrm{~km}$ da cidade de Corrientes, capital da província, a uns $90 \mathrm{~km}$ de Posadas, capital da vizinha Provincia de Misiones e a quase $1.200 \mathrm{~km}$ da cidade de Buenos Aires, Capital Federal.

A história de Ituzaingó encontra-se intimamente associada ao rio Paraná, primeiramente como um importante porto regional e, em seguida, como a sede argentina das obras do projeto Yacyretá. As corredeiras de Apipé, situadas a poucos quilômetros a montante de Ituzaingó, é a razão para a existência desta cidade e para sua atual importância. Isto porque foi devido a estas corredeiras que Ituzaingó se converteu em por- to, pois era necessário canalizar a produção de Misiones até os mercados de Buenos Aires e Asunción. E também, porque foi devido às corredeiras de Apipé que se construiu a usina hidrelétrica de Yacyretá (RIBEIRO, 1999).

Durante a década de 1970 a cidade experimentou com o projeto Yacyretá uma intensa mudança na sua composição demográfica, social e cultural. Ituzaingó, de 3.421 habitantes em 1970, passou a ter 8.636 habitantes em 1980. A população continuou crescendo em ritmo acelerado atingindo 16.995 habitantes em 1991. Em 2001 Ituzaingó contava com 19.073 habitantes (INDEC, 1970, 1980, 1991, 2001).

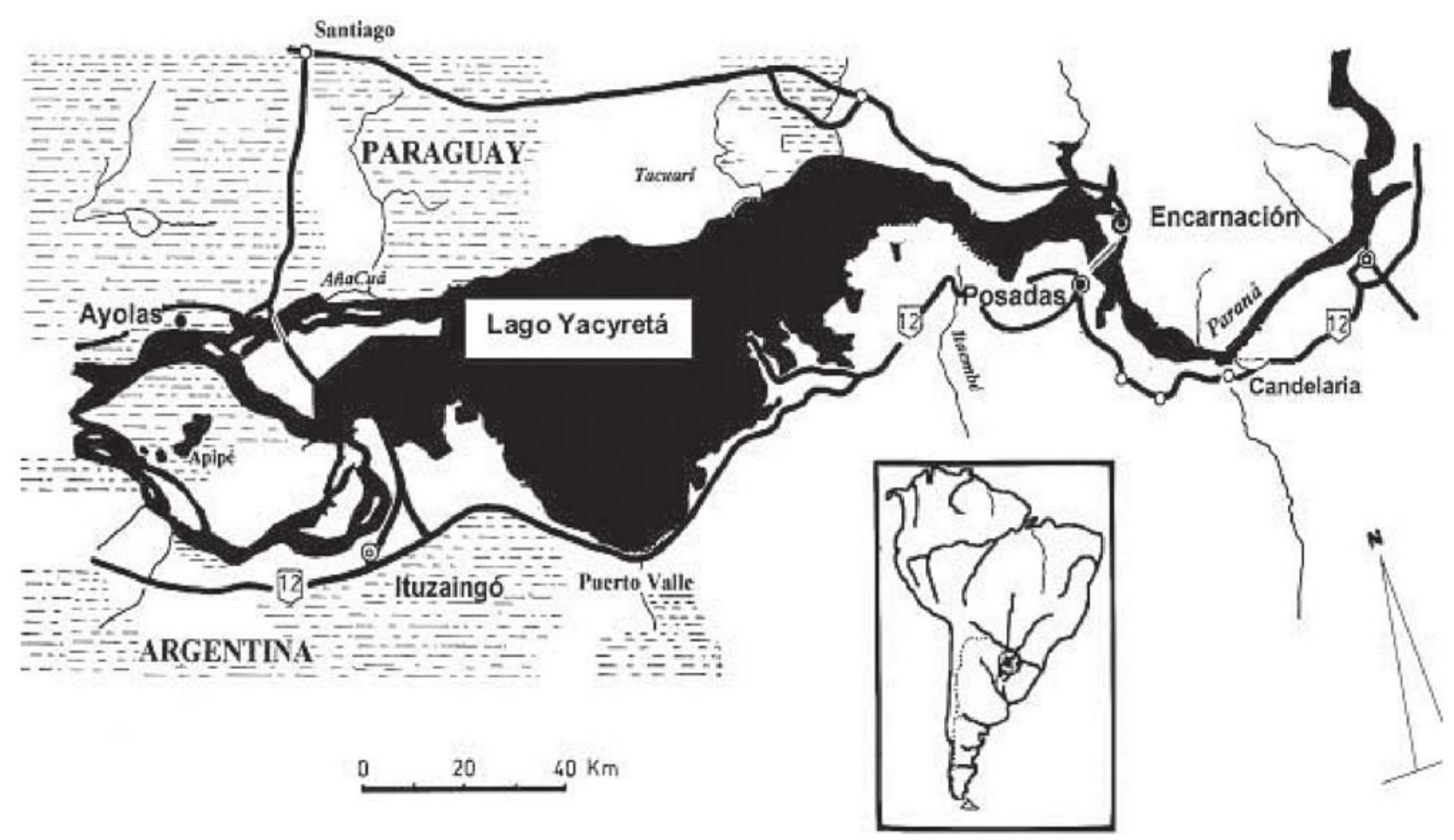

FIGURA 1: Localização da cidade de Ituzaingó (27 36’S, 56º 41’W). Fonte: Modificado de Neiff, 2005.

Atualmente a economia de Ituzaingó fundamenta-se na produção agrícola, pecuária e florestal e, embora incipiente, numa significativa indústria turística.

A maior parte dos pescadores-lavradores de Ituzaingó habitava as ilhas e ribeiras próximas, a montante e a jusante das corredeiras de Apipé. Em 1900, as aproximadamente 300 ilhas da região, apresenta- vam importantes contingentes humanos. Ilhas com habitantes permanentes foram Talavera e Lima, hoje submergidas nas águas do reservatório de Yacyretá. Outras, com importante número de moradores, são as ilhas Apipé Chico, Apipé Grande, San Martín, Toro e Yacyretá. Um número significativo de outras ilhas, contudo, também se apresentavam colonizadas, mas por 
poucas famílias. Ainda, é importante ressaltar que a maioria das ilhas menores era desabitada, pois eram ilhas de recente formação geológica e, consequentemente, baixas e inundáveis.

De acordo com o expressado por Bréard (ENTREVISTA LIVRE, 2005), os moradores das ilhas maiores, Apipé Grande e San Martín, são efetivos proprietários da terra, embora uma grande porção da primeira (65\% sobre um total de 30.000 ha) ainda corresponda a terrenos fiscais pertencentes à Provincia de Corrientes. Os moradores das ilhas restantes também possuíam certa propriedade da terra por gestão ante o governo pela ferramenta legislativa de "usos e costumes”. Já a maior parte das ilhas pequenas, de recente formação, era totalmente estatal.

A maior parte dos ilhéus das ilhas pequenas era nômade em virtude, basicamente, das enchentes. Após cada inundação, nada lhes impedia voltar à sua antiga moradia ou colonizar uma nova ilha. Seu sistema de produção era o de pescadores-lavradores, sistema de produção familiar herdado diretamente dos seus ancestrais indígenas.

Como o ilhéu, os ribeirinhos também aparecem como altamente dependentes do rio, em função do rio ser o principal meio de transporte e também por ser quem fornece sua principal fonte de proteína: o peixe. No entanto, o ribeirinho de Ituzaingó diferenciava-se do ilhéu pelo papel cumprido na navegação do rio Paraná, não apenas como fornecedor de mercadorias em pequena escala (venda de aves, ovos, verduras, etc.) aos grandes barcos, senão que também na comunicação entre os operários desses meios de transporte e seus familiares de terra.

Apesar de sua importância, as pesquisas sobre os processos das transformações socioeconômicos e socioculturais de comunidades tradicionais submetidas a impactos ambientais são escassas no Alto Paraná. No entanto, as poucas investigações sobre comunidades afetadas pela construção de usinas hidrelétricas, como as de pescadores-lavradores do Estado do Paraná, mostram que estes grupos têm sido negligenciados. Um destes estudos é o de Tommasino (1985) que conseguiu investigar mudanças econômicas e culturais na comunidade de pescadores-lavradores de Ilha Grande (ou das Sete Quedas) acompanhando os momentos dramáticos da desocupação da ilha por ocasião do iní- cio das grandes e novas enchentes decorrentes do represamento do rio Paraná a montante. Já Silva (2002) em uma abordagem interdisciplinar, analisou a trajetória e o grau de adaptação dos ex-ilhéus da Ilha Mutum, hoje residentes na cidade de Porto Rico após a construção das barragens de Itaipu e Porto Primavera. Violante (2009), por sua vez, abordou o tema dos pescadores-lavradores neste mesmo local, mostrando como as alterações ambientais causadas pelas hidrelétricas e pelas Áreas de Preservação Ambiental contribuíram para a exclusão desse grupo.

O objetivo do artigo é descrever e analisar as principais transformações socioeconômicas e socioculturais ocorridas nas comunidades de ilhéus e ribeirinhos de Ituzaingó a partir da construção da usina hidrelétrica de Yacyretá. Com essa finalidade, inicialmente, analisou-se alguns dos fatores que possibilitaram a concretização desse projeto, assim como as principais características da comunidade de pescadoreslavradores atingida. Também abordaram-se as contradições mais visíveis no âmbito social, cultural e econômico dessa população.

\section{PROCEDIMENTOS METODOLÓGICOS}

Para se chegar a uma visão ampla dos problemas, delineou-se um percurso metodológico fundamentado nos estudos descritivos. Este tipo de estudo tem como objetivo primordial investigar um determinado problema ou fenômeno ou ainda, o estabelecimento de relações entre variáveis. Contudo é necessário esclarecer que além da simples identificação da existência de relações entre as variáveis, este estudo também procurou determinar a natureza dessas relações para um melhor entendimento das problemáticas (TRIVIÑOS, 1987; GIL, 2007).

Uma prática imprescindível desta pesquisa foi também o emprego de uma metodologia interdisciplinar surgida da necessidade de confrontar diversos problemas teóricos e práticos decorrentes da análise de objetos de complexidade tal como são as transformações sociais a partir da execução dos hidroprojetos. Apesar das limitações dos investigadores, esse trabalho pode ser considerado um aporte à prática interdisciplinar como alternativa válida em face aos novos fenômenos físicos e sociais que ultrapassam a capacidade de co- 
nhecimento e os efeitos previsíveis pelos paradigmas das disciplinas tradicionais (LEFF, 2002).

Assim para a elaboração deste artigo foram compilados e analisados dados obtidos por meio de informações em campo e de bibliografia procedente de diferentes áreas do conhecimento, históricos, geopolíticos, econômicos, culturais, de impactos ambientais associados às grandes barragens, entre outros.

O trabalho de campo para este estudo foi realizado durante 2004 e 2005 com viagens à cidade de Ituzaingó. Durante esse período, se procedeu à busca de bibliografia pertinente e à realização de uma série de entrevistas estruturadas e livres. O roteiro das entrevistas estruturadas foi elaborado, organizado e adaptado a partir dos trabalhos de Tommasino (1985), Ferrara (1999) e Silva (2002).

\section{RESULTADOS E DISCUSSÕES}

\subsection{A usina hidrelétrica de Yacyretá}

O antecedente formal mais importante de Yacyretá data de 15 de setembro de 1926, quando foi subscrito um convênio argentino-paraguaio para legalizar o trabalho conjunto sobre navegabilidade e usos energéticos, mas que nunca chegou a ter vigência efetiva. Em 1958 foi firmado um convênio que criou a Comissão Técnica Mista (CTM) para estudar o aproveitamento do rio Paraná à altura das ilhas Yacyretá e Apipé. Após extensas negociações sobre o traçado da barragem, em 3 de dezembro de 1973 firmou-se o Tratado Binacional de Yacyretá mediante o qual se criou a Entidade Binacional Yacyretá (EBY). Em dezembro de 1974, a CTM transferiu funções e bens à EBY a qual executou o projeto (SOLANAS, 1996; CORTIÑAS, 2004).

Junto com a barragem de Itaipu, Yacyretá é a maior obra pública levada a cabo na América Latina. A área da obra, território binacional, é regulamentada por leis especiais e abrange 1.200 ha. O projeto supõe a construção de um conjunto de obras principais e a execução de uma série de obras complementares. As primeiras, já concluídas, se localizam na ilha Yacyretá, à altura das cidades de Ayolas (Paraguai) e Ituzaingó (Argentina).

O complexo hidrelétrico e suas obras comple- mentares, assim como a energia produzida, são de propriedade conjunta de ambos os países. As obras civis iniciaram-se em 1982 e terminaram em 1992. Atualmente as obras de engenharia e as eletromecânicas estão terminadas e a barragem encontra-se em funcionamento, mas a potencia disponível é inferior (1.710 MW) à programada (2.700 MW) em razão, principalmente, da cota de operação, sensivelmente menor (76 m) à projetada (83 m), e da não conclusão das obras complementares. Estas contemplam a realização de uma diversidade de programas ambientais e de ação social. Uma vez concluídas, Yacyretá terá 20 turbinas (tipo Kaplan) com uma capacidade de geração de 135 MW cada uma, o que representará uma potência conjunta de 2.700 MW.

O projeto possui uma eclusa de navegação, 2 vertedouros, 2 tomadas para irrigação e um reservatório de $1.420 \mathrm{~km}^{2}$ de superfície. A longitude total da represa (incluindo a central, eclusa e vertedouros) é de 72,5 km (75\% dentro do território paraguaio). Yacyretá conta também com obras de infraestrutura, tais como vilas permanentes, acampamentos, caminhos de vinculação e de acesso, uma ponte de $1.500 \mathrm{~m}$ de comprimento sobre o Aña Cuá (braço secundário do Paraná) que conecta a ilha de Yacyretá com o território paraguaio, outra ponte de $980 \mathrm{~m}$ sobre o braço principal do Paraná conectando a ilha com a Argentina, e um aeroporto.

O empreendimento de Yacyretá é uma represa de planície acarretando vários inconvenientes: uma extensa superfície inundada, grandes obras de fechamentos principais e laterais, importantes reassentamentos urbanos e rurais, altos custos de indenizações a particulares e ao Paraguai pela maior porção inundada de território (SOLANAS, 1996). Segundo Neiff (2005), o enchimento do reservatório em 1994 implicou na perda de $1.220 \mathrm{~km}^{2}$.

\subsection{Principais impactos socioculturais registrados no município de Ituzaingó e imediações}

\subsubsection{Reassentamentos forçados urbanos}

O impacto mais intenso de Yacyretá sobre a população urbana de Ituzaingó talvez seja representado pelo período ligado à construção da infraestrutura 
habitacional do projeto (1978-1983), etapa necessária que possibilitaria receber a empreiteira principal e seus empregados que ocupariam essa estrutura habitacional no início de 1984.

A chamada Villa Permanente, conjunto de 300 casas para o pessoal hierárquico do projeto Yacyretá, começou a ser construída em 1978 em uma área periférica contígua a Ituzaingó. A finalização desse projeto aconteceu em 1981. Sua construção implicou reassentar 270 famílias ituzaingueñas. De acordo com Ribeiro (1999), 68\% dessas famílias eram ocupantes ilegais. Para a Municipalidad de Ituzaingó (2004), ao contrário, essas famílias eram os legítimos pioneiros do lugar, que viviam em casas modestas onde podiam ter pequenos animais e plantar algumas verduras, além de mandioca, milho e frutas diversas. Embora esporádicos, a principal fonte de renda dessa população decorria da prestação de serviços para fazendeiros ou habitantes de Ituzaingó.

O reassentamento dessas famílias teve lugar em outra área da cidade em um empreendimento habitacional denominado de 180 Viviendas por meio de um convênio da EBY e da Provincia de Corrientes (MUNICIPALIDAD DE ITUZAINGÓ, 2004).

Segundo a Municipalidad de Ituzaingó (2004), apesar de haver recebido a soma de 300 milhões de pesos, o bairro construído pela Província é uma ofensa à dignidade e aos legítimos direitos dos reassentados, pois além da rápida deterioração de suas casas e do pequeno tamanho dos lotes que impede o cultivo da terra e a cria de animais, os habitantes do bairro 180 Viviendas têm que se adaptar a condições de aglomeração e contaminação extremas.

\subsubsection{Outros impactos urbanos}

A partir de 1970 a cidade de Ituzaingó experimentou com o projeto Yacyretá, uma intensa mudança na sua composição demográfica, social e cultural. A população, que desde os anos 1940 encontrava-se em franca diminuição, sofreu um rápido incremento ao final da década de 1970 com os primeiros sinais do projeto. Somente o anúncio da obra, foi motivo suficiente para a chegada de centenas de trabalhadores migrantes atraídos pelos discursos desenvolvistasmodernizadores habitualmente ligados aos projetos de grande escala.

Esse auge de desenvolvimento trouxe consigo um excesso de população masculina que, em face ao surgimento de uma inflação localizada, tinham que pagar altos preços de aluguel em casas de famílias ou se somar aos sem teto que dormiam em praças e ruas de Ituzaingó. A segurança pública, as usurpações de residências e a prostituição tornaram-se problemas sociais perceptíveis. Esses problemas foram aliviados, em grande parte, pela eventual queda da oferta de empregos verificada no final das obras de infraestrutura em1982, mas fundamentalmente pelo término das obras da ponte que atravessa o braço Aña Cuá em 1983. A partir desse momento, os operários cruzavam para o Paraguai onde os bens e serviços eram bem mais econômicos que do lado argentino (RIBEIRO, 1999).

Outro problema originado pela massiva onda de população masculina é que muitos desses trabalhadores formaram famílias reais, mas que resultaram temporárias. Com o final das obras de infraestrutura, muitos homens abandonaram as famílias que acabavam de formar, criando um número significativo de famílias matriarcais, principalmente nas zonas periféricas de Ituzaingó (MUNICIPALIDAD DE ITUZAINGÓ, 2004).

A construção da Villa Permanente, porém, não somente alterou a vida dos ituzaingueños pela chegada de centenas de trabalhadores migrantes, como também pelo seu abandono massivo após a finalização das obras de infraestrutura e o início das obras civis principais, entre 1982-1983. Estima-se que cerca de 3.000 operários efetivamente participaram na construção da infraestrutura do projeto (BRÉARD, ENTREVISTA LIVRE, 2005). O drama dos altos índices de desemprego verificados em ambos os lados do rio Paraná nesse momento, ficou mascarado por um acontecimento que sacudiu a região: a guerra das Malvinas em 1982.

\subsection{Principais impactos ambientais registrados no município de Ituzaingó e imediações}

\subsubsection{Fauna Íctica}

A maioria dos pescadores da zona de influên- 
cia de Yacyretá alega que os peixes de valor comercial têm desaparecido a montante da barragem. Segundo estes pescadores, o que prevalece hoje no lago e arredores, é uma grande quantia de piranhas (Serrasalmus sp.) e de raias (Dysceus sp.).

Para Oldani e Rabe (2004) o escasso repovoamento íctico nesse trecho do Paraná, não seria senão uma clara conseqüência do represamento do rio. De acordo com ambos pesquisadores, o fechamento de Itaipu em 1982 e o de Yacyretá em 1994, isolaram 665 km do rio Paraná, ou seja, praticamente todo o Alto Paraná. Na prática isto representou uma perda de $44 \%$ da área de reprodução mais importante da bacia do Plata, tendo em conta que originalmente se estendia uns 1.500 km, desde La Paz (Entre Ríos, Argentina) até os Saltos de Guaíra (Paraná, Brasil).

Para o Painel Internacional Assessor sobre Yacyretá de 1999 (BANCO MUNDIAL, 1999), convocado pelo Banco Mundial em 1988, além de alterar um trecho de uns 200 km de hábitats aquáticos, a presença da represa impediu a migração ascendente de peixes no rio Paraná. Do mesmo modo, o Painel identificou esse impacto como irreversível e inevitável para qualquer cota de operação da barragem.

Por outro lado, para os pescadores artesanais, ameaçados e preocupados pela diminuição significativa do recurso nesses últimos anos, o problema não só se resumiria à barreira interposta pela represa, mas também aos manejos dos níveis de água que levam os peixes, a jusante da barragem, a que "abaixem às profundidades ou migrem para lugares mais profundos". A esse respeito, Neiff (ENTREVISTA LIVRE, 2004) aclara:

Los humedales que se encuentran aguas abajo de la represa, y que son el hábitat de los peces de río abierto durante gran parte de su vida, están seriamente comprometidos por la despreocupación sobre este tema. La productividad de los mismos, los flujos de nutrientes, los movimientos de los peces, su alimentación, refugio y otras funciones, dependen de los bañados de la planicie de desborde del río. Estos bañados son como son, por la secuencia de pulsos que produce el río. Cuando las represas alteran el régimen hidrológico, como lo hacen especialmente en el período de aguas muy bajas, se producen alteraciones indeseables en el hábitat de los peces, y muchas de estas modificaciones, no vuelven atrás luego que el río "se normaliza”. De tal manera hay una pérdida de hábitat que es el impacto más importante en el mediano y largo plazo como consecuencia de las represas.

Como resultado da obrigatória inundação desse trecho do rio Paraná junto a alguns dos seus tributários, o Plano Mestre de Manejo Ambiental (PMMA) de 1992 da EBY (ENTIDAD BINACIONAL YACYRETÁ, 1992), já apontava como potencial impacto a eventual diminuição da pesca comercial e de subsistência por distúrbios nos sítios de desova e de cria das comunidades de peixes presentes. Como medida de mitigação anunciada nesse mesmo documento, a EBY propunha atenuar os efeitos negativos mediante o uso da transferência de peixes (elevadores) e repovoamento íctico, por meio da liberação massiva de alevinos das espécies mais afetadas, e a geração de áreas de compensação de desova.

Tal anúncio foi motivo de grandes expectativas para os municípios da região tendo em vista que, além de implicar a "volta dos peixes", essas medidas impunham a construção de importantes obras em ambos os lados do rio Paraná aliviando os seus problemas de desemprego.

Até junho de 2004, de todas essas medidas e projetos comprometidos no PMMA de 1992, somente seria cumprida a referida à transferência de peixes.

\subsubsection{Transferência de peixes}

O sistema de transferência de peixes a partir da instalação de elevadores, proposta apresentada pela EBY com um pressuposto inicial de US\$ 40 milhões, foi duramente questionado tanto pelo Centro de Ecología Aplicada del Litoral (CECOAL) como pelo Instituto Correntino del Agua y del Ambiente (ICAA) ainda antes que a barragem fosse construída (NEIFF, ENTREVISTA LIVRE, 2004).

O que Yacyretá pretendeu com a instalação de elevadores, em comentários de Neiff (ENTREVISTA 
LIVRE, 2004), foi tentar focalizar o efeito da represa sobre a interferência de migrações de peixes através do slogan "Yacyretá mitiga os impactos sobre as populações de peixes mediante um produto de altíssima tecnologia: o elevador”. De acordo com esse investigador, além da exígua eficiência na passagem de peixes, demonstrado em numerosos trabalhos, o sistema instalado não é senão prova de um total desconhecimento do comportamento social dos cardumes.

A ineficiência dessa "inovadora”" tecnologia tem sido abertamente denunciada:

La improvisación y la falta de criterios del pasado llevaron a Yacyretá a instalar los elevadores que en 1963 (hace casi 40 años) ya habían sido declarados universalmente obsoletos. Esos sistemas fueron diseñados para los salmones del hemisferio norte y transportados al hemisferio sur, sin considerar la biología y ecología de nuestros peces (OLDANI; BAIGÚN, 2000).

Para o Painel Internacional Assessor sobre Yacyretá de 1999 (BANCO MUNDIAL, 1999), a existência da operação desses elevadores seria válida somente como alternativa para a manutenção de germoplasma no lago e em ecossistemas águas acima, nunca como um substituto da migração. Remarca ainda, da mesma forma que Neiff (ENTREVISTA LIVRE, 2004), que é totalmente incerto o comportamento dos exemplares ascendidos às calmas águas do reservatório dado que a maior parte das espécies migratórias responde a estímulos de velocidade de corrente.

\subsubsection{Mortandade de peixes: descompressão brusca ou supersaturação gasosa?}

O aparecimento, em agosto de 1994, de aproximadamente 120.000 peixes flutuando águas abaixo da represa foi motivo de sérios conflitos para a EBY, especialmente quando meses mais tarde esse fenômeno voltou a se repetir. Aparentemente, tratou-se de um fato totalmente inesperado e, conseqüentemente, não anunciado no PMMA de 1992 da EBY como impacto potencial.

A causa dessas mortandades massivas de pei- xes tem sido motivo de controvérsias até o presente. Tanto para a EBY como para o Painel Internacional Assessor sobre Yacyretá de 1999 (BANCO MUNDI$A L, 1999)$, as mortalidades de peixes registradas nas águas abaixo da represa teriam como principal causa a supersaturação de gases originada pelo desenho dos vertedouros. Assim mesmo, na ocorrência do fenômeno, destaca-se também a escassez de profundidade do rio, pois os peixes, segundo os técnicos desse Painel, têm mecanismos para compensar os excessos de pressão de gases procurando profundidades onde os gases deixam de estar saturados.

Neiff (ENTREVISTA LIVRE, 2004), contrariando as explicações oferecidas pela EBY e pelo Painel Internacional, considera que a verdadeira causa das mortandades não seria outra senão a rápida descompressão sofrida pelos peixes ao passar de um ambiente com maior pressão atmosférica a outro de menor pressão. Esse processo, também conhecido como “doença da borbulha” ou “doença dos mergulhadores”, segundo esse pesquisador, verificar-se-ia quando, de maneira súbita, peixes situados a vários metros de profundidade são levados até a superfície por turbinas, tubos de aspiração ou outro canal. Como conseqüência, os gases borbulham dentro das artérias e veias e os peixes morrem por hemorragias múltiplas, exoftalmia e até pelo eventual estouro de vísceras.

\subsubsection{Erosão a jusante da obra}

O Estudo de Impacto Ambiental (EIA-RIMA) de 1992, mais conhecido como Plano Estratégico Yacyretá (PEY) de 1992, descartava a possibilidade de que Yacyretá pudesse produzir efeitos negativos águas abaixo sobre o braço principal do rio, pois os caudais que sairiam da represa seguiriam os padrões de comportamento de maneira similar aos anteriores da construção da obra.

Para o Painel Internacional Assessor sobre Yacyretá de 1999 (BANCO MUNDIAL, 1999), porém, na sua análise acerca do tratamento do problema de supersaturação de gases, advertiu que alguns problemas de erosão águas abaixo poderiam ser causados por efeito da instalação de defletores nos vertedouros.

Um breve estudo de campo realizado em março de 2003 pela Municipalidad de Ituzaingó nas cos- 
tas de Apipé Chico, ilha situada frente a Ituzaingó, possibilitou constatar a ativa erosão sofrida pela mesma revelando a real magnitude do problema (FIG. 2). Concretamente:

[...] las erosiones se producen por las bruscas variaciones en las alturas de agua del río
Paraná que se registran en esta zona... Entre los días domingos y lunes de cada semana, las variaciones de alturas de agua indicadas son, en promedio, de unos 0,60 m, (ocurriendo) en muy pocas horas de las mañanas de los días lunes (MUNICIPALIDAD DE ITUZAINGÓ, 2003, p. 1).

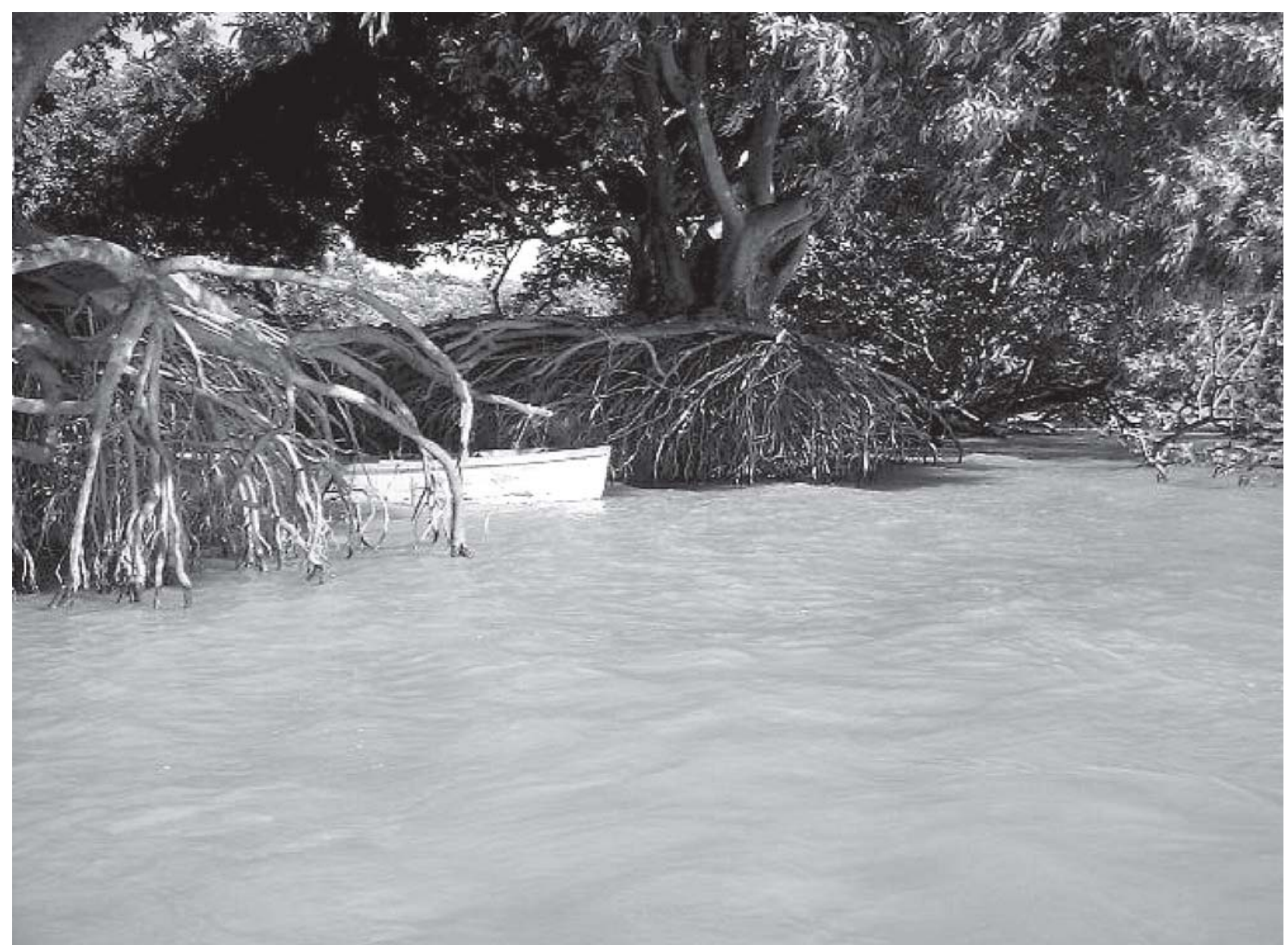

FIGURA 2: Erosão verificada nas costas da ilha Apipé Chico em março de 2003. Fonte: Adolfo Fulquet, 2003.

Em 1994 Yacyretá elaborou um projeto que incluía a construção, nas costas ituzaingueñas, de um conjunto de 15 espigões e uma defesa de costa com rocha do tipo "rip-rap". Além disso, o mesmo projeto chegou a incluir o próprio traslado do porto de San Antonio, principal porto da cidade. De todas essas propostas, a EBY somente chegou a executar 6 dos 15 espigões permanecendo inconclusas todas as medidas restantes (MUNICIPALIDAD DE ITUZAINGÓ, 2004).

\subsubsection{Outros impactos ambientais}

Outros impactos ambientais atribuíveis à barragem de Yacyretá são o reassentamento forçado de etnias indígenas (Mbyá Guarani); perda de jazidas arqueológicas; transbordamento Esteros del Iberá; episódios de florações de Microcystis aeruginosa (cianobactéria) a montante e a jusante do reservatório; a acumulação de sustâncias tóxicas orgânicas e de metais 
pesados provenientes da atividade agrícola e industrial e de efluentes urbanos; sedimentação e diminuição da velocidade da corrente; perda definitiva de 52.600 ha de ecossistemas terrestres; perda do ecossistema de ilhas do Paraná; perda da continuidade biológica da região por fragmentação; perda de vales aluviais dos córregos da bacia do Alto Paraná; impactos negativos sobre espécies de animais e plantas ameaçadas de extinção e perda de espécies de valor particular como os caracóis endêmicos dos corredores de YacyretáApipé (Aylacostoma sp.), e do Tordo Amarillo (Xanthopsar flavus), espécie globalmente ameaçada. Deve ainda ser mencionado o desaparecimento e modificação de cenários paisagísticos (Saltos de Apipé); o desaparecimento de sítios de aproveitamento turístico; mudanças no clima e o aumento da mortandade da fauna por acidentes em estradas (BANCO MUNDIAL, 1999; BONETTO; HURTADO, 1999; PEÑA; STANCICH, 2000; ENTIDAD BINACIONAL YACYRETÁ, 2000, 2002; BLANCO; PARERA, 2003; CECOAL, 2004; LA FAUNA, 2004; MUNICIPALIDAD DE ITUZAINGÓ, 2004; NEIFF, 2004).

\subsection{Yacyretá e os pescadores-lavradores de Ituzaingó}

Meses antes de proceder ao fechamento da barragem em 1994 para a formação do reservatório, a EBY procedeu à evacuação e translado de toda população rural que seria afetada de maneira direta nessa nova fase do projeto. O deslocamento forçado dos habitantes rurais compreendeu todas as famílias assentadas em ilhas ou ribeiras do rio Paraná a montante da obra.

Dos grupos familiares das redondezas do município de Ituzaingó, um total de 29 famílias foram reassentadas em dois bairros com localização e características bem diferentes: 15 Viviendas e Santa Tecla. O primeiro localiza-se próximo ao centro da cidade de Ituzaingó, abrigando, precisamente, 15 famílias. Já o bairro Santa Tecla se assenta na ribeira esquerda do rio Paraná, a $32 \mathrm{~km}$ águas acima da cidade de Ituzaingó. Embora a EBY informasse o reassentamento de 24 famílias nesse último local (quatorze de Ituzaingó mais dez de Posadas) (ENTIDAD BINACIONAL YACYRETÁ, 2006), este estudo constatou somente a presença dos grupos familiares pertencentes a Ituzaingó. Uma peculiaridade de ambos assentamentos é a alta incidência de matrimônios mistos (argentino-paraguaios).

É importante mencionar que o processo de translado e de reassentamento das famílias rurais ituzaingueñas foi coordenado e executado, integralmente, pela EBY. Pressionados pelo Banco Interamericano de Desenvolvimento (BID) e pelo Banco Mundial (BIRF) para finalizar as obras complementares, entre elas, os reassentamentos forçados, a EBY começou, em setembro de 2004, a entrega definitiva de títulos de propriedade aos seus moradores.

Em termos gerais, o bairro 15 Viviendas não difere muito do bairro 180 Viviendas já referido. Além de pequenas, a deterioração das casas é notória, reflexo da má qualidade dos materiais de construção utilizados (FIG. 3).

As características do bairro Santa Tecla, por outro lado, contrastam fortemente com respeito aos bairros 180 Viviendas e 15 Viviendas. Embora, o padrão das casas seja o mesmo das residências dos bairros 180 Viviendas e 15 Viviendas, o tamanho desses 14 terrenos tem, em média, 10 ha cada um, permitindo, de maneira quase satisfatória, a continuidade de todas as atividades anteriores dos seus moradores (FIG. 4). De acordo com o expressado por um executivo da EBY (ENTREVISTA LIVRE, 2004) quando questionado por esse díspare tratamento, as razões últimas do outorgamento de moradias em bairros com características tão diferentes foram, principalmente, a própria desorganização administrativa da EBY e as pressões das agências financiadoras com relação à execução das obras complementares.

É paradoxal a preocupação demonstrada pela EBY por este assentamento em particular. Além de alimentos em abundância durante os seis primeiros meses para todos os seus habitantes, a EBY, em alguns casos, também chegou a entregar instrumentos e insumos agrícolas para a exploração dos terrenos. Houve também fornecimento de gado bovino para trabalho e a alimentação dos moradores. E em vista dos contínuos problemas com os poços artesianos, o bairro agora conta com uma estação de tratamento de água potável em um dos seus extremos, empreendimento também realizado pela EBY. 


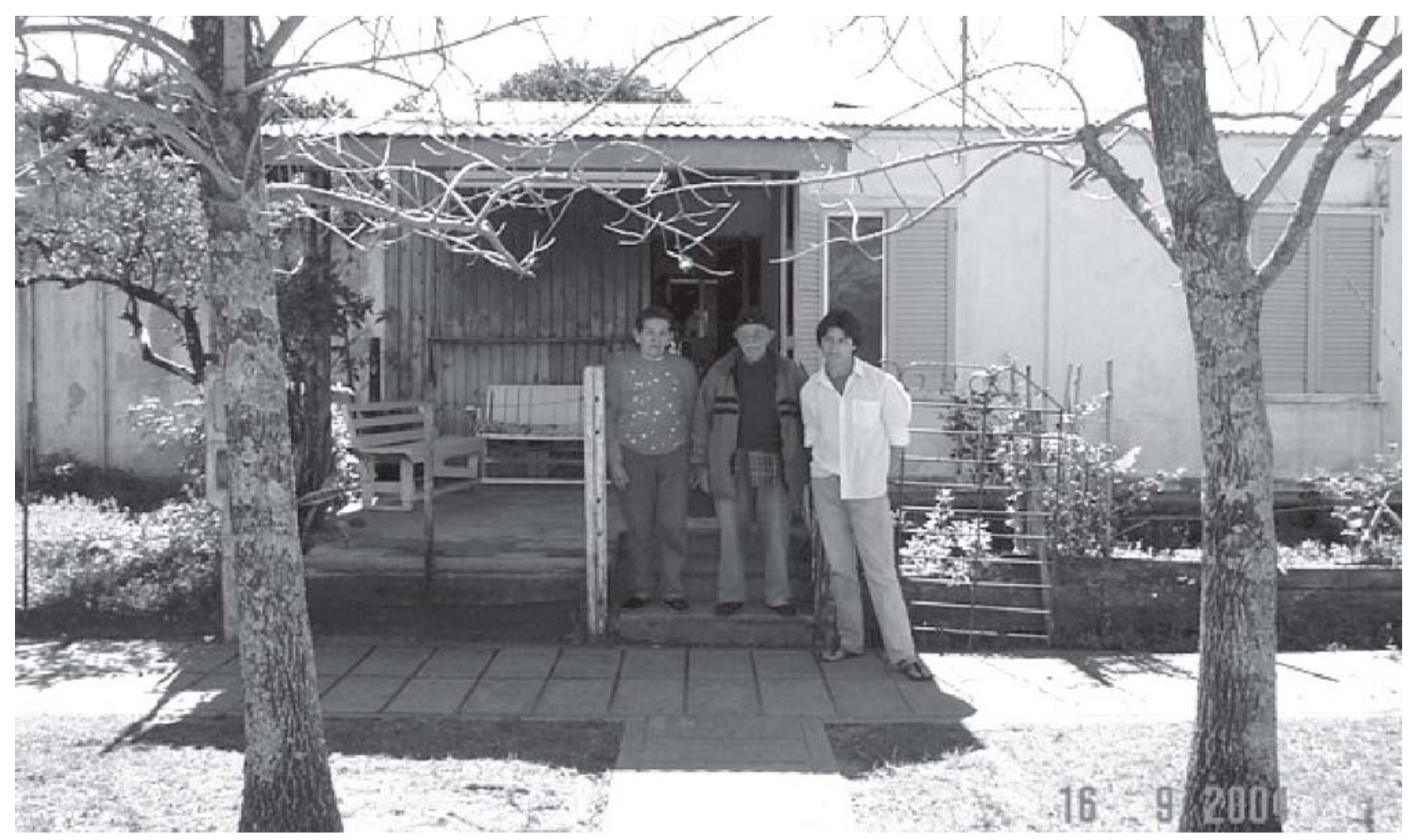

FIGURA 3: Casa de família reassentada do bairro 15 Viviendas de Ituzaingó. Fonte: Víctor Ulloa, 2004.

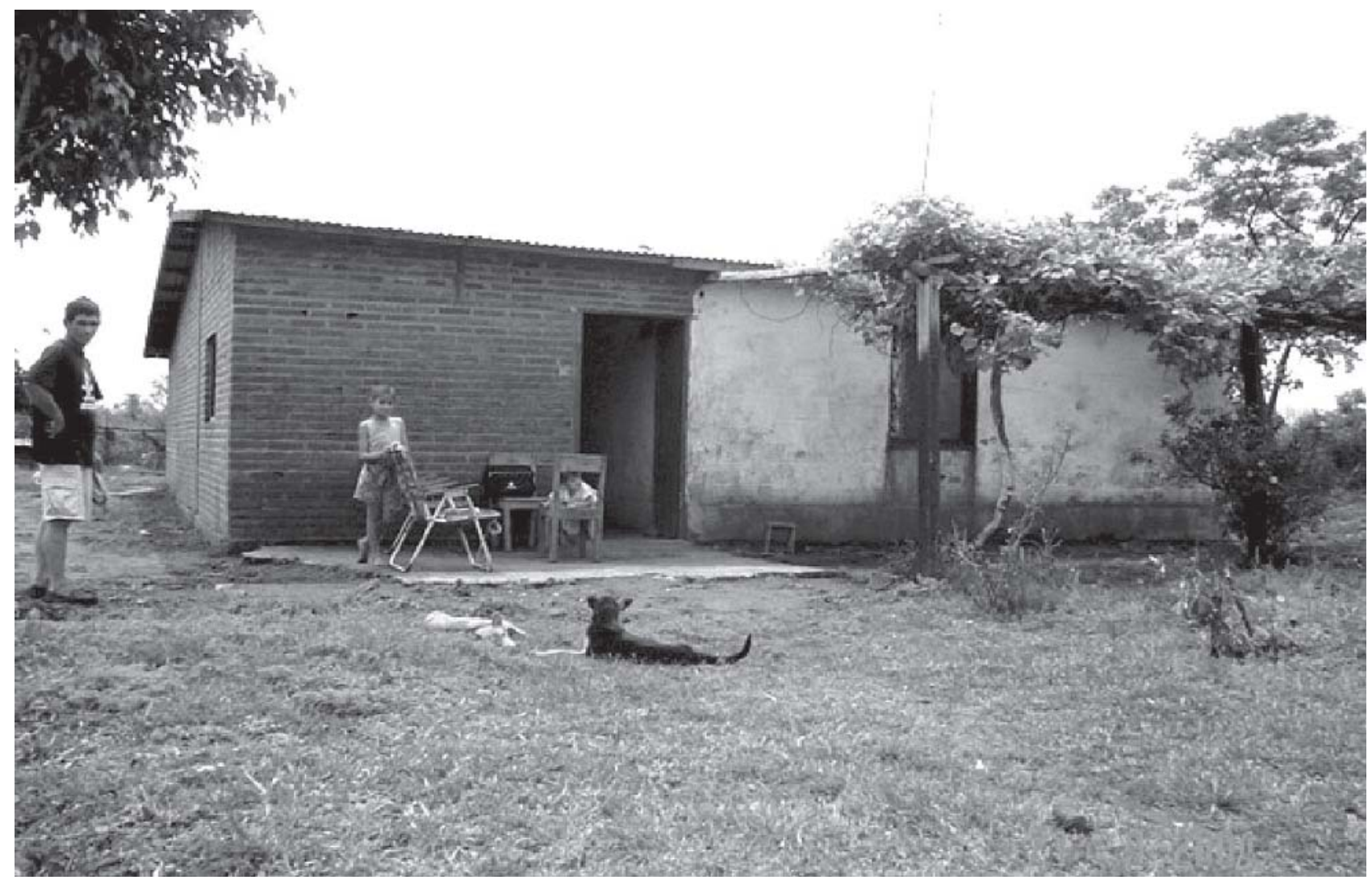

FIGURA 4: Casa de família reassentada da localidade de Santa Tecla, distante 32 km de Ituzaingó. Fonte: Víctor Ulloa, 2004. 
A beleza cênica do local unida à excepcional qualidade das suas terras tem convertido esses terrenos em um importante alvo do mercado imobiliário local e da cidade vizinha de Posadas.

As maiores dificuldades enfrentadas hoje pelos ex-ilhéus e ex-ribeirinhos de Ituzaingó, são principalmente as manifestadas e vivenciadas pelos moradores do bairro 15 Viviendas, o bairro mais agressivo em termos econômico-culturais. Contrariamente ao bairro de Santa Tecla, das 15 famílias originalmente reassentadas em 15 Viviendas, são poucas as casas que abrigam os seus moradores originais. Mais raro ainda é encontrar os chefes de família com vida. A maior parte das casas hoje se apresenta habitada essencialmente por descendentes quando esses resolveram ficar, mas majoritariamente por novos proprietários em ocasião da partida desses. O bairro Santa Tecla, por sua vez, apesar de todas as "mordomias" outorgadas pela EBY quando comparado ao bairro 15 Viviendas, não deixa de ser palco de algumas insatisfações para os seus moradores.

Localizados próximos ao centro histórico de Ituzaingó, a nova realidade e o novo espaço dos exilhéus e ex-ribeirinhos do bairro 15 Viviendas, apresentam-se de modo hostil a todos eles. Como ocorreu com o bairro 180 Viviendas, o tamanho e as características das residências não se enquadra, de modo algum, às necessidades das famílias beneficiadas, sobretudo pela ausência de um terreno adequado para o cultivo e a criação de animais. Atividades, dadas às novas condições de urbanização, muito difíceis de se concretizar. Porém, as maiores queixas desses moradores é quanto à escassez de empregos em Ituzaingó. E, mais do que a escassez de emprego, talvez à ausência de ocupações que eles, efetivamente, sejam capazes de executar:

Aquí en la ciudad hay poco trabajo por mi edad y porque yo no tengo escuela. Sólo sé de pesca y de cortar pasto. [...] Acá no se puede criar chanchos ni una oveja, nada. Ni tener mucha gallina porque a los vecinos les molesta. Y ya te vienen los inspectores de la municipalidad porque ya hay un olorcito, porque esto. Porque uno tiene un perro y entra para matar la gallina, ¿y ahí? Acá no se puede tener lo que uno quiere tener (ENTREVISTADO 1, 2004).

As principais reclamações dos ex-ilhéus do bairro de Santa Tecla apontam, por um lado, à escassez de peixes no rio Paraná e, por outro, as novas características da paisagem que dificultam a obtenção de peixes, assim como de outros itens alimentares:

El río cambió mucho. No hay pescado. Sí, se acabó el pescado. Con esta represa que hay no quedó ni una isla, no hay islas, quedó un mar. Con las islas podíamos ir a pescar más adentro y sacábamos pescado. Ahora no. En la parte de arriba de la represa no hay nada. Se terminó la pesca. Se terminó todo. Para cazar un carpincho no hay más nada, se terminaron todas las islas. Cambió el agua también. No corre más el agua. Acá corre más un poco, pero no es como antes. El agua allá arriba quedó verde, y aquí abajo lo mismo, quedó apagada. [...] El río cambió totalmente. Ahora no es que uno dice voy a ir a sacar un pescado para comer, tenís que andar el día entero para sacar un pescado (ENTREVISTADO 7, 2004).

As críticas comuns a ambos assentamentos são principalmente de ordem cultural: os vizinhos e a sensação de não pertencimento ao lugar. Embora pareça estranho, são escassos os vestígios de laços de amizade ou de cooperação entre as famílias vizinhas. Pelo contrário, o que se verifica são muitas queixas:

Aquí muy poca relación tenemos con los vecinos. Relación tenemos con la gente buena. Hay gente mala también. Yo con la maldad no, no me gusta. Yo me quedo en casa o en mi trabajo (ENTREVISTADO 9, 2004).

Lo que menos me gusta son los vecinos. La mayoría son malos vecinos. Hasta entre hijo y padre se pelean acá. Para decir vecino, para decir "ésto voy a ir a pedirle", no acá no hay (ENTREVISTADO 14, 2004). 
Por causa das condiç̧̃es de aglomeração existentes, essa situação é mais preocupante no bairro 15 Viviendas. Já no bairro Santa Tecla o trabalho de mutirão visando a construção de uma capela no bairro nesses últimos anos, indica uma flexibilização significativa das relações entre essas famílias.

A sensação de não pertencimento ao lugar, por outro lado, aparece como claro distintivo de todos os grupos familiares entrevistados:

Acá vinimos a sufrir. Acá llegamos con dolor de cabeza todo el tiempo de pensar nuestro lugar allá. Allá no se vivía como acá. Allá se vivía tranquilo. Se despejaba la cabeza allá. Vinimos acá y siempre con la cabeza abombada. [...] Allá no faltaba nada porque yo trabajaba en la chacra. Teníamos las cosas. Teníamos cómo vivir. Y acá vinimos y no tenemos nada, no podemos levantar nada. Lo que teníamos tuvimos que vender todo para poder comer acá. Porque acá nosotros no nos ubicábamos, no sabíamos cómo vivir en el pueblo. Acá no hay nada de bueno. Acá si tenés plata comés y si no tenés, no comés. $Y$ allá cuando estábamos en el campo ahí teníamos para comer. Acá tenés que pagar todo (ENTREVISTADO 1, 2004).

Embora essa sensação pudesse ser mais comum e previsível de encontrar entre os chefes de cada família, fundamentalmente pelo seu maior tempo de permanência nas ilhas e ribeiras, esse sentimento aparece muito vivo e compartilhado, sem distinção, por velhos e novos, por pais e filhos de ambos os assentamentos.

Com o objetivo de minimizar os efeitos traumáticos dos reassentamentos e atender necessidades sociais como a capacitação profissional, educação, saúde, regularização dos documentos, adaptação às novas casas, a EBY elaborou e implementou o Plano de Ação Social (PAS) no período 1989-1990. De acordo com Peña e Stancich (2000) o PAS propôs como objetivos gerais:

a) conseguir um reassentamento funcionalmente eficiente da população residente nas áreas afetadas; b) minimizar os impactos potencialmente negativos do reassentamento;

c) promover condições que possibilitem um desenvolvimento independente dos novos assentamentos, como também a integração harmônica ao seu respectivo habitat.

Nenhum desses objetivos foi atingido.

Dada a necessidade de dar uma cobertura maior aos aspectos ambientais da obra e de reestruturar o PAS, em 1992 a EBY elaborou o Plano Estratégico Yacyretá (PEY). O propósito deste plano era expor os conceitos, mecanismos e estrutura com os que a EBY tinha previsto alcançar os diferentes aspectos do projeto. O Programa do Meio Ambiente e Reassentamento, dessa maneira, foi apresentado como um mecanismo cujo objetivo principal era consolidar e executar o Plano Mestre de Manejo Ambiental (PMMA) e o Plano de Ação para o Reassentamento e Reabilitação (PARR). O propósito do PARR de 1992, ainda em vigência, era salvaguardar e melhorar a qualidade de vida das populações afetadas. Dentro do marco do PARR, cabe distinguir também o Plano Operacional de Reassentamento (POR) e o Plano de Reabilitação e Apoio Social (PRAS). O POR compreendia tarefas de preparação das famílias para o traslado e a implementação efetiva dos traslados, a titulação dos imóveis e a recepção das famílias no novo habitat. O PRAS compreendia atividades de promoção social, formulação participativa e autogestão de projetos comunitários com acompanhamento social, que atendessem necessidades da população (ENTIDAD BINACIONAL YACYRETÁ, 1992; PEÑA; STANCICH, 2000; ENTIDAD BINACIONAL YACYRETÁ, 2009).

Excetuado os benefícios iniciais realizados no bairro Santa Tecla, nenhum dos objetivos do PARR foi alcançado.

\section{CONSIDERAÇÕES FINAIS}

É importante aclarar que os mais atingidos pelo fechamento de Yacyretá, não foram, numericamente, os ilhéus e ribeirinhos de Ituzaingó, senão os da vizinha cidade de Posadas, distante quase $100 \mathrm{~km}$ ao leste de Ituzaingó. Seja por despreparo ou por falta de estimativas dos técnicos responsáveis, o concreto é 
que o avanço das águas sobre Posadas foi socialmente calamitoso. Foi esse o evento que marcou o início de uma rede de conflitos entre a EBY e inúmeros órgãos provenientes dos mais diversos setores da Argentina e do Paraguai. Impasses, na sua maioria, sem solução até hoje.

Assim, por humildade, ignorância ou por serem conscientes de sua situação de pioneiros com relação à terra, inicialmente não houve qualquer reação por parte dos ilhéus e dos ribeirinhos de Ituzaingó no sentido de solicitação de assistência oficial ou de reparo de danos. Ao contrario do acontecido com comunidades tradicionais sob impactos no Estado do Paraná (ULLOA, 2006; VIOLANTE, 2009) e outros locais do Brasil (LEONEL, 1998; FEARNSIDE, 2002), foram ONGs e diversas associações civis, muitas vezes alheias ao local em questão, que assumiram esse compromisso por eles. A pressão exercida pelo esforço conjunto de todas essas organizações tem sido de tal magnitude e transcendência que impediu, até hoje, a finalização das obras de Yacyretá.

Tal ocorrência deveria, talvez, ser refletida sob a ótica de conceitos como o de cidadania, entendida como o exercício de direitos civis, políticos e sociais conquistados, ou ainda, da ecocidadania vista como a inclusão da ética ecológica nos pressupostos presentes na concepção clássica de cidadania na medida em que insere a busca e defesa por direitos humanos e pelas demais formas de vida, o senso de responsabilidade social e relativa à natureza, e o senso de pertencimento a uma sociedade global (LOUREIRO, 2002; LOUREIRO, 2000 apud CASTRO E BAETA, 2002). Assim um estudo mais pormenorizado deveria incluir a análise do maior ou menor significado de consciência cidadã desenvolvido nos países em questão.

Já no aspecto sociocultural, fica evidente que não há medida de mitigação alguma capaz de compensar ou preencher a anterior experiência de vida. Em geral, para os ilhéus e ribeirinhos de Ituzaingó reassentados nos bairros 15 Viviendas e Santa Tecla, o pior que aconteceu na vida deles, foi ter que viver na cidade. Para eles não há aspecto nenhum que compense a perda do seu lar anterior. A vida em comunidade (os vizinhos), a impossibilidade de plantar e criar animais, as cercas que delimitam suas casas, são fatores extremamente agressivos que lhes impede de ver ou aceitar qualquer vantagem da sua atual condição. Neste sentido é válido lembrar que os ilhéus ou ribeirinhos de Ituzaingó são, na sua maioria, homens e mulheres nascidos e criados no rio, sem maior experiência longe dele, e com pouca ou mínima comunicação com a cidade. Agrega-se à essa questão, a existência de uma forte tradição Tupi Guarani desse seu modo de vida.

Em outro contexto, após quase 35 anos à frente do Projeto Yacyretá, o desempenho das diferentes administrações da EBY, a respeito da implementação de suas políticas ambientais e sociais, não tem mostrado a rigorosidade esperada para um empreendimento das dimensões de Yacyretá. É o que mostra, por exemplo, a elaboração permanente de uma infinidade de planos e projetos que nunca ou que dificilmente são executados, e os vários casos de improvisação na execução das obras complementares. Um episódio concreto é o acontecido com os bairros Santa Tecla e 15 Viviendas em relação à díspare atenção prestada aos seus moradores. Embora os planos PMMA e PARR apareçam ligeiramente alterados no PEY de 2002, adverte-se uma enorme incredulidade por parte dos afetados com relação à sua concretização.

Em síntese, apesar dos pescadores-lavradores de Ituzaingó terem conseguido significativas compensações na hora de ter que abandonar seus locais de moradia, o impacto do processo de reassentamento no continente foi particularmente traumático; os bairros Santa Tecla e 15 Viviendas sugerem os procedimentos que devem e não devem ser seguidos em matéria de atingidos por barragens; a usina hidrelétrica de Yacyretá, como projeto de desenvolvimento regional sustentável, não promoveu o desenvolvimento de Ituzaingó e região, simplesmente agravou as problemáticas socioambientais prévias.

\section{AGRADECIMENTOS}

Aos professores José Neiff (Centro de Ecologia Aplicada do Litoral - Corrientes) e Miguel Bréard (Centro de Estúdios Antropológicos Guaraníticos Ituzaingó) pelas entrevistas e interesse demonstrado. Ao Amarildo Jorge da Silva pela leitura e sugestões ao presente trabalho. À Mónica Rodrigues pelo auxilio ao inglês. À coordenação de Aperfeiçoamento de Pessoal de Nível Superior (CAPES) pela concessão da bolsa 
de doutorado. Ao PEA e ao Nupélia pela infra-estrutura e recursos oferecidos para a realização deste estudo.

\section{REFERÊNCIAS}

BANCO MUNDIAL. Informe del panel internacional asesor sobre el proyecto hidroeléctrico Yacyretá (Informe de cinta azul). Washington DC, 1999.

BLANCO, D.E.; PARERA, A.F. La inundación silenciosa. El aumento de las aguas en los Esteros del Iberá. Buenos Aires: Fundación Vida Silvestre Argentina, 2003

BONETI, L.W. O silêncio das águas: políticas públicas, meio ambiente e exclusão social. 2 ed. Ijuí: Ed. Unijuí, 2003.

BONETTO, A.A.; HURTADO, S. Cuenca del Plata. In: CANEVARI, P., BLANCO, D., BUCHER, E., CASTRO, G.; DAVIDSON I. (Ed.). Los humedales de Argentina. Clasificación, situación actual y legislación. Buenos Aires: Wetlands International, 1999. p. 31-72.

CARLOS CECCO, testigo privilegiado de las dos vidas de Federación. El Cronista Digital, Federación, 15 out. 2002. Disponível em: <http://www.cronista digital.com.ar>. Acesso em: 02 jul. 2004.

CASTRO, R.S.de.; BAETA, A.M. Autonomia intelectual. In: LOUREIRO, C.F.B.; LAYRARGUES, P.P.; CASTRO, R.S. (Orgs). Educação ambiental: repensando o espaço da cidadania. São Paulo: Cortez, 2002. p. 99-107.

CAUBET, C. G. As Grandes Manobras de Itaipu: energia, diplomacia e direito na Bacia do Prata. São Paulo: Ed. Acadêmica, 1991.

CENTRO DE ECOLOGÍA APLICADA DEL LITORAL (CECOAL). Informe sobre la presencia de algas tóxicas en el río Paraná. Corrientes, 2004.

COMISSÃO MUNDIAL DE BARRAGENS. Barragens e desenvolvimento: um novo modelo para toma- da de decisões. In: SEVÁ FILHO A.O. (Org). Tenotãmõ: alertas sobre as conseqüências dos projetos hidrelétricos no rio Xingu, Pará, Brasil. São Paulo: International Rivers Network, 2005. p. 301-314.

CORTIÑAS, J.C. Yacyretá: el proyecto que no tiene fecha de terminación sin audacia y creatividad. Revista Mercado Eléctrico, Buenos Aires, v. 12, n. 68, p. 1-51, 2004.

ENTIDAD BINACIONAL YACYRETÁ. Plan estratégico Yacyretá 1992, PEY 1992 (Proyecto Hidroeléctrico Yacyretá: Informe de evaluación ambiental). Buenos Aires, 1992.

Informe panel de expertos. Interrelación entre el embalse de Yacyretá y el sistema Iberá. Buenos Aires, 2000.

Informe monitoreo niveles freáticos. Interrelación entre el embalse de Yacyretá y los esteros del Iberá. Buenos Aires, 2002.

Obras y acciones. Disponível em: <http:// www.yacyreta.org.ar>. Acesso em: 15 jan. 2006.

. Reasentamiento. Definiciones y planes. Disponível em: <http://www.yacyreta.org.ar>. Acesso em: 20 ago. 2009.

FEARNSIDE, F. Impactos Sociais da Hidrelétrica de Tucuruí. Manaus: INPA, 2002.

- A hidrelétrica de Balbina: o faraonismo irreversível versus o meio ambiente na Amazônia. São Paulo: Instituto de Antropologia e Meio Ambiente, 1990. 69p.

FERRARA, L. D. Olhar periférico. São Paulo: EDUSP,1999.

FURTADO, C. O mito do desenvolvimento econômico. Rio de janeiro: Paz e Terra, 1974.

GIL, A.C. Métodos e técnicas de pesquisa social. 5 ed. São Paulo: Atlas, 2007. 
INSTITUTO NACIONAL DE ESTADÍSTICA Y CENSOS (INDEC). Censo Nacional de Población, Hogares y Viviendas. Buenos Aires, 1970.

Censo Nacional de Población, Hogares y Viviendas. Buenos Aires, 1980.

Censo Nacional de Población, Hogares y Viviendas. Buenos Aires, 1991.

. Censo Nacional de Población, Hogares y

Viviendas. Buenos Aires, 2001.

JUNK, W.J. Áreas inundáveis: um desafio para a limnologia. Acta amazónica, Manaus, v. 10, n. 4, p. 775-795, 1980.

LA FAUNA misionera está en riesgo y muy poco se hace en su defensa. El Territorio Digital, Posadas, 04 jul. 2004. Disponível em: <http://www.territorio digital.com>. Acesso em: 03 out. 2004.

LEFF, E. Epistemologia ambiental. 3 ed. São Paulo: Cortez, 2002.

LEONEL, M. A morte social dos rios. São Paulo: Perspectiva: IAMÁ: FAPESP, 1998.

LEWIS, W.M.Jr.; WEIBEZAHN, F.H.; SAUNDERS III, J.F.; HAMILTON S.K. The Orinoco river as an ecological system. Interciencia, Caracas, v. 15, p. 346357, 1990.

LOUREIRO, C.F.B. Educação ambiental e movimentos sociais na construção da cidadania ecológica e planetária. In: LOUREIRO, C.F.B.; LAYRARGUES, P.P.; CASTRO, R.S. (Org.). Educação ambiental: repensando o espaço da cidadania. São Paulo: Cortez, 2002. p. 69-98.

MEADOWS, D.L.; MEADOWS, D.H.; RANDERS, J.; BEHRENS, W.W. Limites do Crescimento - um relatório para o Projeto do Clube de Roma sobre o dilema da humanidade. São Paulo: Perspectiva, 1972.

MUNICIPALIDAD DE ITUZAINGÓ. Informe acer- ca de la erosión registrada en la isla Apipé Chico. Ituzaingó, 2003.

Informe acerca del origen, desarrollo y documentos relevantes de la posición institucional del municipio de Ituzaingó frente a las cuestiones socioambientales de Yacyretá. Ituzaingó, 2004.

NEIFF, J.J. Ideas para la interpretación ecológica del Paraná. Interciencia, Caracas, v. 15, n. 16, p. 424441, 1990.

El Iberá ¿En peligro? 1 ed. Buenos Aires: Fundación Vida Silvestre Argentina, 2004.

Sinopsis ecológica del pasado y futuro de la vegetación acuática en el embalse de Yaciretá. Corrientes, 2005. 144f. Tesis (Doctorado en biología) - Facultad de Ciencias Exactas y Naturales y Agrimensura, Universidad Nacional del Nordeste, Corrientes, 2005.

OLDANI N.; BAIGÚN C. Más problemas para los peces del río Paraná. El Diario de Paraná, Paraná, 05 nov. 2000. Disponível em: <http://www.eldiariode parana.com.ar>. Acesso em: 05 dez. 2003.

OLDANI, N.; RABE, E. Surubí, perdónanos. Diario El Territorio, Posadas, 26 jul. 2004. Disponível em: $<$ http://www.territoriodigital.com>. Acesso em: 11 nov. 2004.

PEÑA, E.D.; STANCICH, A. No más daños en Yacyretá: historia, proceso y documentos relevantes del seguimiento de la sociedad civil a la Represa Hidroeléctrica Yacyretã. Asunción: Sobrevivencia, 2000. Disponível em: <http://www.sobrevivencia. org.py>. Acesso em: 21 nov. 2003.

PETRERE JR., M.; AGOSTINHO, A.A. La pesca en el tramo brasileño del Río Paraná. Montevideo: FAO / Informe de Pesca No. 490, 1993. Disponível em: $<$ http://www.fao.org/documents>. Acesso em: $03 \mathrm{fev}$. 2005.

RIBEIRO, G.L. Capitalismo transnacional y política 
hidroenergética en la Argentina. La represa de Yacyretá. Posadas: Editorial Universitaria de Misiones, 1999.

SILVA, E.A.R. Ilhados em Porto Rico - do éden pessoal ao dilúvio social. Maringá, 2002. 185f. Dissertação (Mestrado em Ecologia de Ambientes Aquáticos Continentais) - Departamento de Biologia, Universidade Estadual de Maringá, Maringá, 2002.

SOLANAS, F. Yacyretá: crónicas de un despojo. Buenos Aires: Fundación Imaginar, 1996.

STANFORD, J.A.; WARD, J.V.; LISS, W.J.; FRISSELL, C.A.; WILLIAMS, R.N.; LICHATOWICH, J.A.; COUTANT, C.C. A general protocol for restoration of regulated rivers. Reg Riv. Res. \& Manage., New York, v. 12, p. 391-413, 1996.

TOMMASINO, K. Fugindo do sistema: começo e fim da utopia dos ilhéus do rio Paraná. São Paulo, 1985. 216f. Dissertação (Mestrado em Antropologia Social) - Faculdade de Filosofia, Letras, e Ciências Humanas, Universidade de São Paulo, São Paulo, 1985.

TRIVIÑOS, A.N.S. Introdução à pesquisa em ciências sociais. São Paulo: Atlas, 1987.

ULLOA, V. Usinas hidrelétricas no rio Paraná: insustentabilidade e exclusão social em populações tradicionais de Ituzaingó (Corrientes, Argentina) e Porto Rico (Paraná, Brasil). Maringá, 2006. 137 f. Tese (Doutorado em Ciências Ambientais) - Departamento de Biologia, Programa de Ecologia de Ambientes Aquáticos Continentais, Universidade Estadual de Maringá, Maringá, 2006.

VIOLANTE, A. E rio levou... Impactos de hidrelétricas e unidades de conservação sobre populações tradicionais. Foz do Iguaçu: Ed. Unioeste, 2009.

WARD, J.W.; STANFORD, J.A. Ecological connectivity in alluvial river ecosystems and its disruption by flow regulation. Reg Riv. Res. \& Manage., New York, v.11, p. 105-119, 1995.
WARD, J.V., TOCKNER, K., SCHIEMER, F. Biodiversity of floodplain river ecosystems: ecotones and connectivity. Reg Riv. Res. \& Manage., New York, v. 15, p. 125-139, 1999. 